\title{
Pengaruh Rasio Aktivitas dan Likuiditas terhadap Profitabilitas pada Perusahaan Manufaktur Sub Sektor Food And Beverage yang Terdaftar di Bursa Efek Indonesia
}

\author{
Ni Putu Indah Pradina Tasya ${ }^{1 *}$, Wayan Cipta ${ }^{2}$ \\ ${ }^{123}$ Program Studi Manajemen, Fakultas Ekonomi, Universitas Pendidikan Ganesha, Singaraja, Indonesia \\ *pradimatasya22@gmail.com ${ }^{l *}$
}

\section{Abstrak}

Penelitian ini bertujuan untuk menguji pengaruh rasio: (1) aktivitas dan likuiditas terhadap profitabilitas, (2) aktivitas terhadap likuiditas, (3) aktivitas terhadap profitabilitas, dan (4) likuiditas terhadap profitabilitas pada perusahaan manufaktur sub sektor food and beverage. Desain penelitian yang digunakan adalah kuantitatif kausal. Subjek penelitian adalah perusahaan manufaktur sub sektor food and beverage yang terdaftar di Bursa Efek Indonesia dan objek penelitian adalah rasio aktivitas, likuiditas dan profitabilitas. Data dikumpulkan dengan pencatatan dokumen, dan dianalisis dengan analisis jalur (path analysis). Hasil penelitian menunjukkan bahwa (1) rasio aktivitas dan likuiditas berpengaruh terhadap profitabilitas (2) rasio aktivitas berpengaruh positif terhadap likuiditas (3) rasio aktivitas berpengaruh positif terhadap profitabilitas (4) likuiditas berpengaruh positif terhadap profitabilitas.

Kata Kunci: Rasio Aktivitas, Likuiditas dan Profitabilitas

\section{Abstract}

This study aims to examine the effect of the ratio: (1) activity and liquidity on profitability, (2) activity on liquidity, (3) activity on profitability, and (4) liquidity on profitability in manufacturing companies in the food and beverage sub sector. The research design used is quantitative causal. The research subject is a manufacturing company in the food and beverage sub-sector listed on the Indonesia Stock Exchange and the object of research is the ratio of activity, liquidity and profitability. Data was collected by documents recording, and analyzed by path analysis. The results showed that (1) the activity ratio and liquidity had a effect on profitability (2) the activity ratio had a positive effect on liquidity (3) the activity ratio had a positive effect on profitability (4) Liquidity had a positive effect on profitability.

Keywords: Activity Ratio, Liquidity And Profitability

\section{Pendahuluan}

Perusahaan manufaktur merupakan perusahaan yang kegiatannya membeli bahan baku kemudian mengolahnya dengan mengeluarkan biaya-biaya lain melalui proses mekanis, kimia atau dengan menggunakan tangan sehingga menjadi barang jadi yang memiliki nilai tambah dan siap untuk dijual. News.detik.com (2016) menyatakan bahwa industri manufaktur merupakan salah satu penopang perekonomian nasional yang memberikan kontribusi pada pertumbuhan ekonomi Indonesia. Hal tersebut terlihat dari adanya peningkatan kualitas dan output yang dihasilkan perusahaan lokal sehingga mampu bersaing di pasar internasional, terutama di bidang industri makanan dan minuman.

Perusahaan Food And Beverage adalah salah satu sektor perusahaan manufaktur yang bergerak dibidang industri makanan dan minuman. Di Indonesia perusahaan Food And Beverage sangat berkembang dengan pesat. Dilihat dari jumlah perusahaan yang terdaftar di Bursa Efek Indonesia dari periode ke periode semakin banyak. Perusahaan Food And

\footnotetext{
History:

Received: 23 Februari 2021

Revised: 26 Juni 2021

Accepted: 28 Juni 2021

Published: 30 Juni 2021
}

Publisher: Undiksha Press

Licensed: This work is licensed under

a Creative Commons Attribution 3.0 License

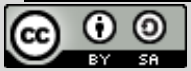


Beverage dipilih karena memegang peranan penting dalam memenuhi kebutuhan konsumen, khususnya pada saat Pandemi COVID-19. Perusahaan Food And Beverage masih bertahan dibandingkan dengan sektor lain karena dalam kondisi apapun sebagian produk makanan dan minuman tetap dibutuhkan. Sebab produk ini menjadi kebutuhan pokok bagi masyarakat seluruh Indonesia. Di Indonesia perusahaan yang bergerak dibidang industri makanan dan minuman sudah sangat banyak, baik itu perusahaan kecil ataupun perusahaan besar maka adanya persaingan usaha yang begitu ketat. Untuk menjaga kelangsungan hidup suatu perusahaaan tentunya perusahaan memerlukan manajemen yang baik didalam menghadapi banyaknya persaingan yang ada sehingga tujuan suatu perusahaan dapat tercapai dimasa yang akan datang. Pada dasarnya setiap perusahaan akan melakukan berbagai aktivitas untuk mencapai tujuan yang telah ditetapkan oleh perusahaan untuk memenuhi kepentingan para stakholder. Harjito dan Martono (2005) menyatakan bahwa tujuan suatu perusahaan antara lainyaitu memperoleh keuntungan atau laba yang maksimal. Dengan memperoleh laba yang maksimal, maka perusahaan dapat mempertahankan kelangsungan hidupnya dan dapat terus berkembang serta memberikan pengembalian yang menguntungkan.

Barus dan Leliani (2013) menyatakan bahwa keberlangsungan hidup perusahaan dipengaruhi oleh banyak hal diantaranya yaitu profitabilitas perusahaan itu sendiri. Profitabilitas merupakan salah satu faktor untuk menilai baik buruknya kinerja perusahaan atau kemampuan perusahaan untuk memperoleh laba. Keuntungan atau laba merupakan sarana penting untuk mempertahankan kelangsungan hidup suatu perusahaan. Semakin tinggi laba yang diharapkan maka perusahaan akan mampu bertahan hidup, tumbuh dan berkembang didalam menghadapi banyaknya persaingan. Munawir (2012) menyatakan bahwa profitabilitas digunakan untuk mengukur efisiensi penggunaan modal dalam suatu perusahaan dengan membandingkan antara modal atau total aset yang digunakan, profitabilitas diproksikan dengan Return On Asset (ROA) yang digunakan untuk mengukur efektivitas perusahaan didalam menghasilkan keuntungan atau laba dengan memanfaatkan total aset yang dimiliki oleh perusahaan.

Dalam penelitian ini digunakan dua faktor yang mempengaruhi Profitabilitas yaitu Rasio Aktivitas dan Likuiditas. Menurut Horne dan Wachowicz (2009) menyatakan bahwa profitabilitas dapat dicapai jika perusahaan efisien dalam menggunakan rasio aktivitasnya begitupun dengan tingkat likuiditas perusahaan. Berdasarkan hal tersebut, bahwa rasio aktivitas dan likuiditas secara bersama-sama berpengaruh terhadap profitabilitas. Adapun Faktor pertama yang dapat mempengaruhi profitabilitas adalah Rasio Aktivitas. Syafri (2001), menyatakan bahwa Rasio Aktivitas adalah rasio yang menggambarkan aktivitas yang dilakukan perusahaan dalam menjalankan operasinya baik kegiatan penjualan dan kegiatan lainnya. Kasmir (2016) menyatakan bahwa rasio aktivitas adalah rasio yang digunakan untuk mengukur efektivitas perusahaan dalam menggunakan aktiva yang dimilikinya. Rasio aktivitas juga digunakan untuk menilai kemampuan perusahaan dalam melaksanakan aktivitas sehari-hari. Rasio yang digunakan untuk mengukur rasio aktivitas dalam penelitian ini adalah Perputaran Modal Kerja (Working Capital Turnover).

Faktor kedua yang mempengaruhi Profitabilitas adalah Likuiditas. Kasmir (2016) menyatakan bahwa likuiditas merupakan kemampuan suatu perusahaan untuk memenuhi kewajiban jangka pendeknya. Yang artinya apabila perusahaan ditagih, maka perusahaan akan mampu untuk memenuhi utang tersebut terutama hutang yang telah jatuh tempo. Perusahaan yang memiliki tingkat likuiditas yang tinggi tentunya dianggap menjadi prospek yang baik. Sebaliknya dengan tingkat likuiditas yang rendah maka akan menjadi tanda awal permasalahan akan modal yang dapat menyebabkan kegagalan bisnis. Jika perusahaan meningkatkan jumlah utang sebagai sumber dananya hal tersebut dapat meningkatkan risiko keuangan. Untuk itu likuiditas berpengaruh terhadap aliran dana yang dibutuhkan oleh 
perusahaan untuk mencapai target perusahaan tersebut. Likuiditas dalam penelitian ini diukur dengan Rasio Lancar (Current Ratio).

Tabel 1. Rasio Aktivitas (WCT) dan Likuiditas (CR) Terhadap Profitabilitas (ROA) pada Perusahaan Manufaktur Sub Sektor Food And Beverage yang Terdaftar di Bursa Efek Indonesia

\begin{tabular}{lcccc}
\hline \multicolumn{1}{c}{ Nama Perusahaan } & Tahun & $\begin{array}{c}\text { Rasio Aktivitas } \\
(\mathbf{\%})\end{array}$ & $\begin{array}{c}\text { Likuiditas } \\
(\mathbf{\%})\end{array}$ & $\begin{array}{c}\text { Profitabilitas } \\
(\mathbf{\%})\end{array}$ \\
\hline \multirow{2}{*}{ PT Garudafood Putra Putri Jaya Tbk } & 2018 & 5,12 & 1.18 & 10,10 \\
\cline { 2 - 5 } & 2019 & 4,22 & 1,53 & 8,60 \\
\hline \multirow{2}{*}{ PT. Indofood CBP Sukses Makmur Tbk } & 2018 & 2,72 & 1,95 & 13,55 \\
\cline { 2 - 5 } & 2019 & 2,54 & 2,54 & 13,84 \\
\hline \multirow{2}{*}{ PT Nippon Indosari Corpindo Tbk } & 2018 & 1,47 & 3,57 & 2,89 \\
\cline { 2 - 5 } & 2019 & 1,78 & 1,69 & 0,05 \\
\hline
\end{tabular}

Berdasarkan Tabel 1 dapat diketahui bahwa terjadi penurunan rasio aktivitas PT Garudafood Putra Putri Jaya Tbk sebesar 5,12\% menjadi 4,22\% diikuti dengan meningkatnya likuiditas sebesar $1.18 \%$ menjadi $1,53 \%$ dan menurunnya profitabilitas sebesar $10,10 \%$ menjadi 8,60\%. Pada PT. Indofood CBP Sukses Makmur terjadi penurunan rasio aktivitas sebesar $2,72 \%$ menjadi $2,54 \%$, diikuti dengan meningkatnya likuiditas sebesar $1,95 \%$ menjadi $2,54 \%$ dan meningkatnya profitabilitas sebesar $13,55 \%$ menjadi $13,84 \%$. Hal ini tidak sesuai dengan teori Horne dan Wachowicz (2009) menyatakan bahwa profitabilitas dapat dicapai jika perusahaan efesien dalam menggunakan Rasio aktivitasnya begitu juga dengan tingkat likuiditas perusahaan. jika perusahaan tidak mampu menghasilkan profitabilitas yang cukup, maka perusahaan tersebut tidak akan mampu untuk menjaga kelangsungan usahanya.

Berdasarkan Tabel 1 dapat diketahui bahwa terjadi penurunan rasio aktivitas pada PT Garudafood Putra Putri Jaya Tbk sebesar 5,12\% menjadi 4,22\% diikuti dengan meningkatnya likuiditas sebesar 1,18\% menjadi 1,53\%. Pada PT. Indofood CBP Sukses Makmur Tbk terjadi penurunan rasio aktivitas sebesar $2,72 \%$ menjadi $2,54 \%$ dan meningkatnya likuiditas sebesar 1,95\% menjadi 2,54\%. Namun pada PT Nippon Indosari Corpindo Tbk terjadi peningkatan rasio aktivitas sebesar $1,47 \%$ menjadi $1,78 \%$ diikuti dengan menurunnya likuiditas sebesar 3,57\% menjadi 1,69\%. Hal ini tidak sejalan dengan teori sutrisno (2012) yang menyatakan bahwa semakin tinggi tingkat rasio aktivitas berarti semakin besar likuiditas, sebaliknya semakin rendah rasio aktivitas berarti semakin rendah likuiditas perusahaan.

Berdasarkan Tabel 1 diketahui bahwa terjadi penurunan likuiditas pada PT Nippon Indosari Corpindo Tbk sebesar 3,57\% menjadi 1,69\%. diikuti dengan menurunnya profitabilitas sebesar 2,89\% menjadi 0,05\%. Pada PT Garudafood Putra Putri Jaya Tbk mengalami peningkatan likuiditas sebesar $1,18 \%$ menjadi $1,53 \%$ diikuti dengan menurunnya profitabilitas sebesar 10,10\% menjadi 8,60\%. Hal ini tidak sejalan dengan teori Harjito, dan Martono (2005) yang menyatakan bahwa makin tinggi likuiditas maka makin baiklah posisi perusahaan di mata kreditur sehingga kreditur tak akan ragu meminjamkan dana mereka yang digunakan perusahaan untuk menambah rasio aktivitas yang nantinya akan memberikan keuntungan bagi perusahaan.

Berdasarkan latar belakang di atas, maka perumusan masalah dalam penelitian ini adalah sebagai berikut: (1) Bagaimana pengaruh Rasio Aktivitas dan Likuiditas terhadap Profitabilitas pada perusahaan manufaktur sub sektor Food And Beverage yang terdaftar di Bursa Efek Indonesia. (2) Bagaimana pengaruh Rasio Aktivitas terhadap Likuiditas pada 
perusahaan manufaktur sub sektor Food And Beverage yang terdaftar di Bursa Efek Indonesia. (3) Bagaimana pengaruh Rasio Aktivitas terhadap Profitabilitas pada perusahaan manufaktur sub sektor Food And Beverage yang terdaftar di Bursa Efek Indonesia. (4) Bagaimana pengaruh Likuiditas terhadap Profitabilitas pada perusahaan manufaktur sub sektor Food And Beverage yang terdaftar di Bursa Efek Indonesia.

Tujuan dari penelitian ini adalah untuk menguji hal-hal sebagai berikut: (1) Pengaruh Rasio Aktivitas dan Likuiditas terhadap Profitabilitas pada perusahaan manufaktur sub sektor Food And Beverage yang terdaftar di Bursa Efek Indonesia. (2) Pengaruh Rasio Aktivitas terhadap Likuiditas pada perusahaan manufaktur sub sektor Food And Beverage yang terdaftar di Bursa Efek Indonesia. (3) Pengaruh Rasio Aktivitas terhadap Profitabilitas pada perusahaan manufaktur sub sektor Food And Beverage yang terdaftar di Bursa Efek Indonesia. (4) Pengaruh Likuiditas terhadap Profitabilitas pada perusahaan manufaktur sub sektor Food And Beverage yang terdaftar di Bursa Efek Indonesia.

Secara teoretis, penelitian ini diharapkan dapat memberikan kontribusi dan manfaat bagi pengembangan ilmu penelitian dalam bidang manajemen keuangan khususnya mengenai pengaruh Rasio Aktivitas dan Likuidasi terhadap Profitabilitas. Disamping itu, secara praktis penelitian ini diharapkan bermanfaat sebagai masukan dan dapat mengetahui informasi serta sebagai bahan pertimbangan untuk mengevaluasi, meperbaiki, dan meningkatkan kinerja manajemen dimasa yang akan datang yang diperoleh dari Rasio Aktivitas dan Likuidasi terhadap Profitabilitas.

\section{Hubungan Antara Rasio Aktivitas (WCT) Dan Likuiditas (CR) Dengan Profitabilitas (ROA)}

Horne dan Wachowicz (2009) menyatakan bahwa profitabilitas dapat dicapai jika suatu perusahaan efisien dalam menggunakan modal kerjanya, begitu pula dengan tingkat likuiditas perusahaan. Berdasarkan hal tersebut, bahwa perputaran modal kerja dan likuiditas secara bersama-sama berpengaruh terhadap profitabilitas. Modal kerja selalu dalam keadaan operasi atau berputar dalam perusahaan selama perusahaan yang bersangkutan dalam keadaan usaha. Teori ini sejalan dengan hasil penelitian Rachminiar, dkk (2018) yang menyatakan bahwa secara bersama-sama terdapat pengaruh positif dan signifikan antara perputaran modal kerja (WCT) dan likuiditas (CR) terhadap profitabilitas (ROA).

$H_{1}$ : Terdapat pengaruh antara Rasio Aktivitas (WCT) dan Likuiditas (CR) terhadap Profitabilitas (ROA) pada perusahaan manufaktur sub sektor Food And Beverage yang terdaftar di Bursa Efek Indonesia.

\section{Hubungan Antara Rasio Aktivitas (WCT) Dengan Likuiditas (CR)}

Nilai penting dari likuiditas perusahaan adalah untuk memenuhi sejumlah dana yang diperlukan pada saat dibutuhkan. Ketidakmampuan perusahaan dalam memenuhi likuiditasnya akan mempengaruhi aktivitas usahanya. Sementara itu dalam manajemen modal kerja penting dalam hal penyediaan dana maupun penggunaan dana yang berkaitan dengan aktivitas usaha. Sutrisno (2012) menyatakan bahwa jumlah aktiva lancar yang rendah menunjukkan bahwa likuiditas perusahaan juga rendah, sehingga akan meningkatkan risiko ketidakmampuan perusahaan untuk memenuhi kewajiban finansial jangka pendeknya (likuiditas). Sebaliknya jika perputaran modal kerja meningkat likuiditas perusahaan akan meningkat. Teori ini sesuai dengan hasil penelitian Ariani, dkk (2016) yang menyatakan bahwa perputaran modal kerja (WCT) berpengaruh positif dan signifikan terhadap likuiditas (CR).

$\mathrm{H}_{2}$ : Terdapat pengaruh antara Rasio Aktivitas (WCT)terhadap Likuiditas (CR) perusahaan manufaktur sub sektor Food And Beverage yang terdaftar di Bursa Efek Indonesia. 


\section{Hubungan Antara Rasio Aktivitas (WCT) Dengan Profitabilitas (ROA)}

Husnan (2002) menyatakan bahwa perputaran modal kerja semakin tinggi dan perusahaan semakin efisien yang pada akhirnya profitabilitas semakin meningkat begitu juga sebaliknya, jika modal kerja perusahaan terlalu kecil akan ada risiko proses produksi perusahaan kemungkinan besar akan terganggu dan menyebabkan profitabilitas menurun.

Dengan mengelola modal kerja maka akan mendatangkan keuntungan dalam kegiatan operasional karena kemungkinan perusahaan dapat beroperasi secara ekonomis dan efisien, perusahaan juga tidak mengalami kesulitan keuangan. Semakin cepat menjadi kas maka semakin cepat perusahaan memperoleh laba dan akhirnya akan meningkatkan profitabilitas. Teori ini juga sejalan dengan hasil penelitian Arimbawa dan Badera (2018) menyatakan bahwa perputaran modal kerja (WCT) berpengaruh positif terhadap profitabilitas (ROA).

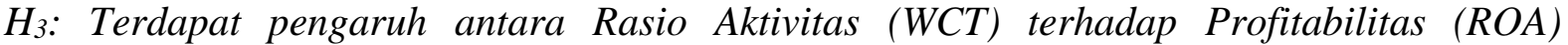
perusahaan manufaktur sub sektor Food And Beverage yang terdaftar di Bursa Efek Indonesia.

\section{Hubungan Antara Likuiditas (CR) Dengan Profitabilitas (ROA)}

Handono Mardiyanto (2008) menyatakan bahwa makin tinggi likuiditas maka semakin baiklah posisi perusahaan di mata kreditur, sehingga kreditur tak akan ragu untuk meminjamkan dana mereka yang nantinya digunakan perusahaan untuk menambah modal sehingga akan memberikan keuntungan bagi perusahaan. sehingga hal itu tentu saja akan meningkatkan profitabilitas bagi perusahaan, dan juga apabila likuiditas menurun, maka profitabilitas akan berkurang, teori ini sejalan dengan hasil penelitian Ambarwati, dkk (2015) menyatakan bahwa likuiditas (CR) berpengaruh signifikan terhadap profitabilitas (ROA).

$H_{4}$ : Terdapat pengaruh antara Likuiditas $(C R)$ terhadap Profitabilitas (ROA) perusahaan manufaktur sub sektor Food And Beverage yang terdaftar di Bursa Efek Indonesia

\section{Metode}

Penelitian ini dilakukan untuk mengetahui pengaruh kompensasi dan motivasi kerja terhadap kinerja karyawan PT. Indah Permai Cabang Singaraja. Terdapat tiga variabel yang diteliti yaitu kompensasi, motivasi kerja, dan kinerja karyawan. Desain penelitian adalah semua proses penelitian yang dilakukan oleh penulis dalam melaksanakan penelitian mulai dari perencanaan sampai dengan pelaksanaan penelitian yang dilakukan pada waktu tertentu.

Desain penelitian yang digunakan adalah desain penelitian kuantitatif kausal, yaitu mengkaji sebab akibat antara faktor tertentu yang menjadi penyebab gejala yang diselidiki. Langkah-langkah desain penelitian kuantitatif kausal adalah sebagai berikut: 1) merumuskan masalah, 2) mengkaji teori, 3) merumuskan hipotesis, 4) mengumpulkan data, 5) mengelola data, 6) menarik kesimpulan.

Subjek penelitian ini adalah karyawan pada PT. Indah Permai Cabang Singaraja yang berjumlah 45 karyawan, sedangkan objek penelitian ini adalah kompensasi, motivasi kerja dan kinerja karyawan pada PT. Indah Permai Cabang Singaraja. Adapun subjek dari penelitian ini adalah para karyawan yang ada pada PT. Indah Permai Cabang Singaraja. Penelitian ini menggunakan penelitian populasi. Populasi menurut (Sugiyono, 2011) populasi adalah "wilayah generalisasi yang terdiri atas obyek/subyek yang mempunyai kualitas dan karakteristik tertentu yang ditetapkan oleh peneliti untuk dipelajari dan kemudian ditarik kesimpulannya". Populasi dalam penelitian ini adalah seluruh karyawan PT. Indah Permai Cabang Singaraja yaitu sebanyak 45 orang. Penelitian ini dikategorikan sebagai penelitian populasi karena semua populasi dijadikan sebagai unit pengamatan atau sasaran penelitian.

Jenis data dalam penelitian ini adalah data kuantitatif. Data kuantitatif dalam penelitian ini adalah skor jawaban responden mengenai kompensasi, motivasi kerja, dan kinerja 
karyawan pada PT Indah Permai Cabang Singaraja. Dalam penelitian ini sumber data yang digunakan adalah data primer. Data Primer diperoleh dari jawaban responden melalui penyebaran kuesioner kepada karyawan yang menjadi responden terpilih. Data penelitian ini berupa informasi melalui pengisian kuesioner mengenai kompensasi, motivasi kerja dan kinerja karyawan yang diperoleh dari jawaban responden.

\section{Hasil dan Pembahasan}

Uji Normalitas bertujuan untuk menguji apakah residual data yang digunakan dalam model telah terdistribusi secara normal. Model yang baik adalah yang memiliki residual data yang terdistribusi normal.Metode yang lebih handal adalah dengan melibat normal probability plot yang membandingkan distribusi kumulatif dari distribusi normal (Ghozali, 2011). Uji normalitas dengan menggunakan metode normal probability plot menunjukkan, data berada disekitar garis diagonal, maka moel regresi memenuhi asumsi normalitas hal ini berarti bahwa model regresi tersebut berdistribusi normal.

Uji multikolinearitas bertujuan untuk menguji apakah dalam model regresi ditemukan adanya korelasi antar variabel bebas. Dalam model regresi yang baik seharusnya tidak terjadi korelasi di antara variabel bebas. Salah satu carauntuk mengetahui adanya gejala multikolinieritas adalah dengan melakukan perbandingan antara koefisien determinasi simultan variabel bebas terhadap variabel terikat pada fungsi regresi variabel tersebut dengan koefisien determinasi antara variabel bebaspada fungsi regresi auxilary. Apabila tolerance value lebih tinggi dari 0,10 atau variance inflation factor $(V I F)$ lebih kecil daripada 10 maka disimpulkan tidak terjadi multikolinearitas.

Hasil uji multikorelasi menunjukan output nilai tolerancedari variabelkinerja karyawan lebih besar dari 0,1 atau $(0,122>0,1)$ dan nilai VIF lebih kecil dari 10 atau $(8,180<10)$ serta untuk variabel motivasi kerja nilai torelarance lebih besar dari $0,1(0,122>01)$ dan nilai VIF lebih kecil dari $10(8,180<10)$. Jadi dari pemaparan hasil output SPSS uji multikolinieritas dapat disimpulkan bahwa tidak ada gejala multikolinieritas dalam model regresi penelitian ini.

Dalam persamaan regresi berganda perlu juga diuji mengenai sama atau tidaknya varians dari residual observasi yang satu dengan observasi yang lainnya. Jika residualnya mempunyai varians yang sama, disebut terjadi gejala homoskedastisitas, dan jika variansnya berbeda disebut terjadi gejala heteroskedastisitas. Persamaan regresi yang baik adalah jika tidak terjadi heteroskedastisitas. Analisis uji asumsi Heteroskedastisitas dilakukan melalui grafik scatterplot (Ghozali, 2011).

Hasil uji heteroskedastisitas dengan scatter plot dapat diketahui bahwa titik-titik residual menyebar dengan pola yang tidak teratur di atas dan di bawah angka 0 (nol) pada sumbu Y. Dengan demikian dapat diambil kesimpulan bahwa pada model regresi tidak terdapat masalah heteroskedastisitas dan residu mempunyai ragam yang homogen, sehingga uji heteroskedastisitas dapat terpenuhi.

Hasil uji determinasi menunjukkan nilai $R$ Square sebesar 0,759 atau 75,9\%. Hal ini menunjukkan bahwa sumbangan pengaruh kompensasi dan motivasi kerja terhadap kinerja karyawan PT Indah Permai Cabang Singaraja sebesar 75,9\%. Dalam arti lain variabel kinerja karyawan PT Indah Permai Cabang Singaraja dapat dijelaskan atau dipengaruhi oleh variabel kompensasi dan motivasi kerja sebesar $75,9 \%$, sedangkan sisanya yaitu sebesar $24,1 \%$ dijelaskan atau dipengaruhi oleh variabel lain yang tidak dimasukkan dalam model regresi pada penelitian ini.

Berdasarkan hasil analisis data pada variabel kompensasi dan motivasi kerja terhadap kinerja karyawan pada PT Indah Permai Cabang Singaraja dengan menggunakan metode analisis regresi linier berganda yang dibantu oleh program Statistical Package for Social 
Science (SPSS) 18.0 for Windows, maka dapat diperoleh hasil analisis dengan persamaan sebagai berikut.

$$
\begin{aligned}
& Y=\alpha+\beta_{1} X_{1}+\beta_{2} X_{2}+\varepsilon \\
& Y=-4,483+0,745 X_{1}+0,421 X_{2}
\end{aligned}
$$

Interpretasi hasil analisis regresi linier berganda sebagai berikut.

1. Konstanta sebesar $-4,483$ artinya bahwa apabila kompensasi $\left(\mathrm{X}_{1}\right)$, dan motivasi kerja $\left(\mathrm{X}_{2}\right)$ nilainya sama dengan nol, maka kinerja karyawan $(\mathrm{Y})$ sebesar $-4,483$

2. Nilai koefisien kompensasi $\left(\beta_{1}\right)$ sebesar 0,745 berpengaruh positif terhadap kinerja karyawan (Y). Hal ini mengandung arti bahwa setiap kenaikan kompensasi $\left(\mathrm{X}_{1}\right)$ satu satuan maka nilai kinerja karyawan (Y) akan mengalami peningkatan sebesar 0,745 dengan asumsi bahwa variabel bebas yang lainnya tetap.

3. Nilai koefisien motivasi kerja $\left(\beta_{2}\right)$ sebesar 0,421 berpengaruh positif terhadap kinerja karyawan (Y). Hal ini mengandung arti bahwa motivasi kerja $\left(\mathrm{X}_{2}\right)$ satu satuan maka nilai kinerja karyawan (Y) akan mengalami peningkatan sebesar 0,421 dengan asumsi bahwa variabel bebas yang lainnya tetap.

Hasil penelitian menunjukkan bahwa kompensasi karyawan PT Indah Permai Cabang Singaraja belum optimal. Hal ini ditunjukkan dari para karyawan terhadap kurang puasnya pendapatan yang diberikan oleh perusahaan yang diberikan oleh perusahaan PT. Indah Permai Cabang Singaraja. Pimpinan yang kurang memberikan pendapatan yang sesuai terhadap kinerja karyawan memberikan dampak negatif terhadap para karyawan. Karyawan akan menjadi kurang maksimal dalam melakukan pekerjaannya didalam perusahaan. Ini dapat mempengaruhi kinerja karyawan yang semestinya bekerja dengan baik tetapi karena kurangnya kompensasi yang diberikan oleh perusahaan para karyawan merasakan rasa yang kurang puas terhadap kompensasi yang diberikan oleh perusahaan.

Pimpinan seharusnya mampu untuk mengetahui apa yang para karyawan cari didalam melakukan pekerjaan dan jika pimpinan sadar dan mengetahui apa tujuan dari karyawan bekerja pastinya kinerja karyawan pasti lebih baik. Karyawan bekerja pastinya untuk mencari penghasilan yang sesuai dengan kebutuhannya, bukan hanya sekedar bekerja dan selalu dituntut melakukan kinerja yang baik tetapi imbalannya masih kurang dan tidak sesuai dengan kebutuhan karyawan tiap individu. Pimpinan juga seharusnya dapat meminta para karyawan pada setiap individunya untuk menyampaikan pendapat dan keluhan masingmasing kepada perusahaan agar pimpinan dan para atasan terbuka didalam berkomunikasi. Tetapi hal itu belum dilaksanakan pada perusahaan ini yang dimana sebenarnya itu hal yang sangat penting untuk dapat menjalin hubungan baik antara karyawan dengan pimpinan. Karena jika adanya keterbukaan dari pimpinan dan sesama karyawan, hubungan baik pastinya akan terjalin dan dapat memberikan masukan satu sama lain.

Sebenarnya saran dan masukan dari karyawan terhadap perusahaan sangatlah penting, agar perusahaan juga tau apa yang dirasa kurang oleh karyawan dan apa yang perlu dibenahi oleh pihak atasan demi mendapatkan kinerja karyawan yang baik untuk memajukan perusahaan. Jika itu belum direalisasikan maka kompensasi yang seharusnya didapatkan oleh karyawan secara adil masih dalam kategori kurang wajar, dan pastinya dapat mengakibatkan kepada kinerja karyawan pada perusahaan ini. Berdasarkan hasil penelitian yang dilakukan menunjukkan bahwa nilai t hitung untuk variabel kompensasi sebesar 5.584 lebih besar dari nilai $t$ tabel sebesar 1,681 dengan tingkat signifikansi.0,000<0,05, hingga $\mathrm{H}_{0}$ ditolak dan $\mathrm{H}_{\mathrm{a}}$ diterima. Kompensasi berpengaruh signifikan terhadap kinerja karyawan pada PT. Indah Permai Cabang Singaraja. Hasil penelitian ini sesuai dengan penelitian oleh Yuda Supriatna (2019) yang menyatakan hasil penelitiannya bahwa kompensasi mempunyai pengaruh signifikan terhadap kinerja karyawan. Hal ini ditunjukkan dari peningkatan kompensasi 
dengan adanya pemberian bonus berupa tambahan kepada karyawan yang dapat menyelesaikan pekerjaan melebihi target yang telah ditentukan perusahaan.

Hasil penelitian hipotesis kedua menunjukkan bahwa motivasi kerja karyawan PT Indah Permai Cabang Singaraja belum optimal.Hasil penelitian menunjukkan bahwa kompensasi karyawan PT. Indah Permai Cabang Singaraja belum optimal. Hal ini ditunjukkan dari para karyawan terhadap kurang puasnya pendapatan yang diberikan oleh perusahaan yang diberikan oleh perusahaan PT. Indah Permai Cabang Singaraja. Pimpinan yang kurang memberikan pendapatan yang sesuai terhadap kinerja karyawan memberikan dampak negatif terhadap para karyawan. Karyawan akan menjadi kurang maksimal dalam melakukan pekerjaannya didalam perusahaan. Ini dapatr mempengaruhi kinerja karyawan yang semestinya bekerja dengan baik tetapi karena kurangnya kompensasi yang diberikan oleh perusahaan para karyawan merasakan rasa yang kurang puas terhadap kompensasi yang diberikan oleh perusahaan. Pimpinan seharusnya mampu untuk mengetahui apa yang para karyawan cari didalam melakukan pekerjaan dan jika pimpinan sadar dan mengetahui apa tujuan dari karyawan bekerja pastinya kinerja karyawan pasti lebih baik. Karyawan bekerja pastinya untuk mencari penghasilan yang sesuai dengan kebutuhannya, bukan hanya sekedar bekerja dan selalu dituntut melakukan kinerja yang baik tetapi imbalannya masih kurang dan tidak sesuai dengan kebutuhan karyawan tiap individu. Pimpinan juga seharusnya dapat meminta para karyawan pada setiapindivoidunya untuk menyampaikan pendapat dan keluhan masing-masing kepada perusahaan agar pimpinan dan para atasan terbuka didalam berkomunikasi. Tetapi hal itu belum dilaksanakan pada perusahaan ini yang dimana sebenarnya itu hal yang sangat penting untuk dapat menjalin hubungan baik antara karyawan dengan pimpinan. Karena jika adanya keterbukaan dari pimpinan dan sesama karyawan, hubungan baik pastinya akan terjalin dan dapat memberikan masukan satu sama lain.

Sebenarnya saran dan masukan dari karyawan terhadap perusahaan sangatlah penting, agar perusahaan juga tau apa yang dirasa kurang oleh karyawan dan apa yang perlu dibenahi oleh pihak atasan demi mendapatkan kinerja karyawan yang baik untuk memajukan perusahaan. Jika itu belum direalisasikan maka kompensasi yang seharusnya didapatkan oleh karyawan secara adil masih dalam kategori kurang wajar, dan pastinya dapat mengakibatkan kepada kinerja karyawan pada perusahaan ini. Berdasarkan hasil penelitian yang dilakukan menunjukkan bahwa nilai t hitung untuk variabel kompensasi sebesar 5.584 lebih besar dari nilai $\mathrm{t}$ tabel sebesar 1,681 dengan tingkat signifikansi.0,000<0,05, hingga $\mathrm{H}_{0}$ ditolak dan $\mathrm{H}_{\mathrm{a}}$ diterima. Kompensasi berpengaruh signifikan terhadap kinerja karyawan pada PT. Indah Permai Cabang Singaraja. Hasil penelitian ini sesuai dengan penelitian oleh Yuda Supriatna (2019) yang menyatakan hasil penelitiannya bahwa kompensasi mempunyai pengaruh signifikan terhadap kinerja karyawan. Hal ini ditunjukkan dari peningkatan kompensasi dengan adanya pemberian bonus berupa tambahan kepada karyawan yang dapat menyelesaikan pekerjaan melebihi target yang telah ditentukan perusahaan.

Hasil penelitian hipotesis ketiga penelitian yang sudah dilakukan diperoleh nilai $\mathrm{f}$ hitung yaitu sebesar 65,983 dengan probabilitas $0,000<\alpha=0,05$. Karena signifikansi atau probabilitasnya jauh lebih kecil dari 0,05 yang berarti Ha diterima, maka model regresi dapat digunakan untuk memprediksi pengaruh variabel dependen ataukompensasi. Jadi dari hasil pengujian secara simultan atau uji statistik F, dapat disimpulkan bahwa Kompensasi dan motivasi kerja secara bersama-sama atau simultan berpengaruh signifikan terhadap kinerja karyawan pada PT. Indah Permai Cabang Singaraja, dengan kata lain untuk meningkatkan kinerja karyawan maka kompensasi dan motivasi kerja secara bersama-sama harus di tingkatkan pula dengan begitu maka kinerja dari karyawan akan meningkat. 


\section{Simpulan dan Saran}

Berdasarkan pemaparan diatas makan dapat disimpulkan bahwa kompensasi berpengaruh terhadap kinerja karyawan pada PT. Indah Permai Cabang Singaraja, Motivasi kerja berpengaruh terhadap kinerja karyawan pada PT. Indah Permai Cabang Singaraja, Kompensasi dan motivasi kerja berpengaruh secara simultan terhadap kinerja karyawan pada PT. Indah Permai Cabang Singaraja.

Adapun saran penulis untuk pihak manajemen PT. Indah Permai Cabang Singaraja agar lebih memperhatikan kompensasi yang diberikan kepada karyawan agar tergolong wajar dan dapat memenuhi kebutuhan individu para karyawan. Dan untuk adanya sebuah dorongan motivasi kerja kepada karyawan sangatlah penting, karena dengan adanya dorongan motivasi baik dari atasan maupun sesama rekan kerja maka dengan demikian kinerja karyawan dapat meningkat dan para karyawan dapat menyelesaikan tugas masing-masing yang diberikan oleh perusahaan dengan maksimal dan akan berdampak baik kepada perusahaan guna mencapai tujuan perusahaan yang ingin dicapai bersama. Penelitian ini membuktikan bahwa kompensasi dan motivasi kerja dapatmempengaruhi kinerja karyawan. Pihak manajemen harus memperhatikan para karyawan melalui pemberian gaji agar disesuaikan dengan kebutuhan individu para karyawan dan agar tergolong wajarsesuai dengan bidang pekerjaannya, serta perlu adanya jika dari pihak perusahaan maupun atasan sendiri untuk memberikan bonus bagi karyawan yang memiliki keuletan dan ketekunan atau dalam mencapai target masing-masing pada pekerjaannya dalam memajukan perusahaan. Selain itu juga dari pihak perusahaan dapat memberikan jaminan kesejahteraan di masa depan, sedangkan bagi karyawan yang sudah bekerja cukup lama diberikan promosi yang berupa kenaikan jabatan, Bagi peneliti selanjutnya yang tertarik untuk mengkaji aspek yang serupa yaitu pengaruh kompensasi, motivasi kerja terhadap kinerja karyawan diharapkan untuk mengembangkan penelitian ini dengan menggunakan populasi dan sampel yang lebih luas agar hasil penelitian lebih teruji keadalannya. Disamping itu, diharapkan untuk menguji variabel lain yang diduga kuat dapat mempengaruhi kinerja karyawan.numerikal.

\section{Daftar Pustaka}

Armstrong, \& Baron. (2001). Manajemen Kinerja.Edisi Ketiga. Cetakan Ke-6. Jakarta : Wibowo.

Damayanti, \& Dkk. (2013). Pengaruh Motivasi dan Pemberdayaan Karyawan Terhadap Kinerja Karyawan PT. HD Motor 99 Denpasar. Vol.5,No.1, Hlm.7272-7299.

Mangkunegara, P. . (2009). Evaluasi Kinerja Sumber Daya Manusia. Bandung: Penerbit Refika Aditama. Bandung : Refika Aditama.

Rivai, S. (2013). Manajemen Sumber Daya Manusia untuk Perusahaan dari Teori ke Praktik.Cetakan ke-5. Jakarta : PT. Raja Grafindo.

Sugiyono. (2011). Metode Penelitian Pendidikan. Bandung : Alfabeta.

Sutrisno, E. (2009). Manajemen Sumber Daya Manusia Edisi Pertama. Jakarta : Kencana Media Group. 